\title{
NBBS isolated from Pygeum africanum bark exhibits androgen antagonistic activity, inhibits AR nuclear translocation and prostate cancer cell growth
}

\author{
Maria Papaioannou • Sonja Schleich • Daniela Roell • \\ Undine Schubert • Tamzin Tanner • Frank Claessens • \\ Rudolf Matusch • Aria Baniahmad
}

Received: 22 July 2009 / Accepted: 11 August 2009

(C) Springer Science + Business Media, LLC 2009

Summary Extracts from Pygeum africanum are used in
the treatment of prostatitis, benign prostatic hyperplasia
(BPH) and prostate cancer (PCa). The ligand-activated
human androgen receptor (AR) is known to control the
growth of the prostate gland. Inhibition of human AR is
therefore a major goal in treatment of patients. Here, we
characterize the compound N-butylbenzene-sulfonamide
(NBBS) isolated from P. africanum as a specific AR
antagonist. This antihormonal activity inhibits AR- and
progesterone receptor- (PR) mediated transactivation, but
not the related human glucocorticoid receptor (GR) or the
estrogen receptors (ER $\alpha$ or ER $\beta$ ). Importantly, NBBS
inhibits both endogenous PSA expression and growth of
human PCa cells. Mechanistically, NBBS binds to AR and
inhibits its translocation to the cell nucleus. Furthermore,
using a battery of chemically synthesized derivatives of NBBS

Electronic supplementary material The online version of this article (doi:10.1007/s10637-009-9304-y) contains supplementary material, which is available to authorized users.

M. Papaioannou $\cdot$ D. Roell $\cdot$ U. Schubert $\cdot$ A. Baniahmad $(\triangle)$ Institute of Human Genetics, Jena University Hospital, 07743 Jena, Germany

e-mail: aban@mti.uni-jena.de

S. Schleich $\cdot$ R. Matusch

Institute for Pharmaceutical Chemistry,

Philipps-University Marburg,

35032 Marburg, Germany

T. Tanner $\cdot$ F. Claessens

Division of Biochemistry, Faculty of Medicine,

University of Leuven,

3000 Leuven, Belgium we revealed important structural aspects for androgen antagonism and have identified more potent AR antagonistic compounds. Our data suggest that NBBS is one of the active compounds of $P$. africanum bark and may serve as a naturally occurring, novel therapeutic agent for treatment of prostatic diseases. Thus, NBBS and its derivatives may serve as novel chemical platform for treatment prostatitis, BPH and PCa.

Keywords Antihormone - Prostate cancer - N-butylbenzenesulfonamide $\cdot$ Natural compound $\cdot$ Pygeum africanum . Androgen receptor

$\begin{array}{ll}\text { Abbreviations } \\ \text { AR } & \text { Human androgen receptor } \\ \text { BPH } & \text { Benign prostate hyperplasia } \\ \text { CPA } & \text { Cyproterone acetate } \\ \text { C4-2 } & \text { a LNCaP derivative cell line that exhibits } \\ & \text { androgen-independent growth } \\ \text { CV1 } & \text { Kidney cell line from green monkey, lacking } \\ & \text { endogenously expressed functional AR, GR, } \\ & \text { ER, PR and TR } \\ \text { DHT } & \text { Dihydrotestosterone, androgen agonist } \\ \text { E2 } & \text { Estradiol } \\ \text { ER } & \text { Human estrogen receptor } \\ \text { GAPDH } & \text { Glyceraldehyde-3-phosphate dehydrogenase } \\ \text { GFP } & \text { Green fluorescent protein } \\ \text { GR } & \text { Human glucocorticoid receptor } \\ \text { HBD } & \text { Hormone binding domain } \\ \text { LNCaP } & \text { a human prostate cancer cell line, exhibits } \\ \text { LacZ } & \text { hormone-dependent growth } \\ \text { Luc } & \text { B-galactosidase expression vector used for } \\ \text { MMTV } & \text { normalization of transfection efficiency } \\ \text { NBBS } & \text { Luciferase } \\ & \text { Mouse mammary tumor virus } \\ & \end{array}$




\begin{tabular}{|c|c|}
\hline $\mathrm{OH}-\mathrm{F}$ & Hydroxyflutamide, androgen antagonist \\
\hline $\mathrm{PCa}$ & Prostate cancer \\
\hline $\mathrm{C} 3$ & $\begin{array}{l}\text { a human prostate cancer cell line, lacking } \\
\text { endogenously expressed functional AR }\end{array}$ \\
\hline PC3-ARwt & $\begin{array}{l}\text { stable transfected PC } 3 \text { cell line, expressing } \\
\text { human wild type AR }\end{array}$ \\
\hline PSA & Prostate specific antigen \\
\hline PR & gesterone receptor \\
\hline qRT-PCR & $\begin{array}{l}\text { reverse transcription polymerase } \\
\text { ion }\end{array}$ \\
\hline R1881 & Methyltrienolone, androgen agonist \\
\hline RLU & $\begin{array}{l}\text { Relative light units (normalized to internal } \\
\text { control) }\end{array}$ \\
\hline T3 & Thyroid hormone (3,5,3'-triiodothyronine) \\
\hline TR & Thyroid hormone receptor \\
\hline$\left(\mathrm{DR}_{4}\right)_{2}$ & $\begin{array}{l}\text { Two direct repeats as known TR response } \\
\text { elements }\end{array}$ \\
\hline
\end{tabular}

\section{Introduction}

Benign prostate hyperplasia $(\mathrm{BPH})$ and prostate cancer (PCa) are serious health problems worldwide and $\mathrm{PCa}$ is the second leading cause of cancer mortality of men in western countries [1-3]. Due to the increase in life span of men the occurrence of PCa is increasing steadily $[4,5]$. The current therapies have significant limitations since the tumour eventually becomes resistant to the therapy [6]. Therefore the development of new therapies against $\mathrm{PCa}$ is a major challenge.

Many factors affect risk of developing $\mathrm{PCa}$, important being age and the circulating male androgens [7]. With advancing age the prostate gland increases in size leading often to BPH. In addition older men develop more chances for having a diagnosis for PCa. Similarly, proliferation of prostate and $\mathrm{PCa}$ is enhanced by androgens $[3,5,8]$.

The current therapies have the goal to inactivate the androgen receptor (AR). The AR regulates male sex differentiation, is responsible for male fertility and promotes the growth of normal prostate gland but also promotes the proliferation of cancer cells of the prostate and therefore has become the most important drug target for PCa therapy $[5,9]$.

The AR induces the expression of AR-responsive genes, when it is bound to androgens. The inactivation of $A R$ is achieved by reducing androgen production and by treating with androgen antagonists. So far synthetic androgen antagonists are used for therapies: Hydroxyflutamide (OH-F), casodex (bicalutamide) and cyproterone acetate (CPA). These clinical strategies have the major goal to inactivate the transactivation of human AR.

However, eventually during the therapy the cancer regrows exhibiting resistance to this hormone ablation therapy. It has been found that AR is present and still remains active and promotes growth of prostate cells despite the treatments aimed at inactivating the receptor $[7,9,10]$.

How the receptor becomes reactivated despite the therapy remains largely unclear. One mechanism is based on the findings that AR becomes mutated. These mutations often lead to a receptor that has gained the ability to promiscuously bind also to non-androgenic ligands and therefore can be activated by other ligands [11, 12] and thus bypassing the androgen ablation or hormone therapy by androgen antagonists. For example, the mutation T877A of human AR, isolated from PCa patients, renders the complete antagonist $\mathrm{OH}-\mathrm{F}$ to an agonist that activates AR [13-15].

A lipophilic extract from the bark of Pygeum africanum (Tadenan ${ }^{\circledR}$ ) is a plant-derived drug, which is commonly used to prevent and treat BPH and PCa $[16,17]$. The bark of Pygeum africanum [18], an evergreen tree growing in Africa is traditionally used to treat the "old men disease". The bark of Pygeum africanum is licensed in Italy, France and other European countries for the treatment of symptomatic BPH. This extract was shown to reduce prostate size in rats [19].

In this study we aimed to gain some insights into the action of the compound N-butylbenzene-sulfonamide (NBBS), which we have previously isolated from bark extracts of $P$. africanum [20].

\section{Materials and methods}

Plant materials

Bark material of Pygeum africanum was a gift of Euromed S.A., Barcelona, Spain. A voucher specimen (No. 8438102) is deposited at the Department of Pharmaceutical Chemistry, Philipps-University of Marburg, Germany. The extract preparation has been described elsewhere [20].

\section{Chemicals and hormones}

Dexamethasone, progesterone, 3,5,3'-triiodothyronine (T3), dihydrotestosterone (DHT), estradiol $\left(\mathrm{E}_{2}\right)$ and NBBS were obtained from Sigma. Methyltrienolone (R1881) was obtained from Perkin Elmer and hydroxyflutamide (OH-F) from LKT Laboratories, Inc. All test compounds were dissolved in ethanol or/and dimethylsulfoxide (DMSO), except T3, which was dissolved in $50 \mathrm{mM} \mathrm{NaOH}$. These compounds were added to the culturing medium such that the final concentration of ethanol and/or DMSO did not exceed $0.1 \%$. Control incubations (no test compounds) were performed in the presence of only $0.1 \%$ ethanol and/or DMSO.

All chemicals used for synthesis of NBBS derivatives were obtained from Aldrich Chem. Co. USA, except of 4Fluorobenzenesulfonylchloride obtained from Acros Organics, USA, that was used for the synthesis of S6. 
General procedure for the synthesis of the sulfonamides S1-S14

0.2 moles of the primary amine were stirred at room temperature under solvent-free conditions and $0.1 \mathrm{~mol}$ of the corresponding arylsulfonyl chloride was added dropwise (development of heat). After cooling down, $100 \mathrm{ml}$ of water were added and the reaction product was extracted with methylene chloride $(3 \times 50 \mathrm{ml})$. The solvent was evaporated to give the pure product (yield $95-100 \%$ ).

\section{Nomenclature according to IUPAC}

$\begin{array}{ll}\text { S1 } & \text { N-Methylbenzene-sulfonamide } \\ \text { S2 } & \text { N-Ethylbenzene-sulfonamide } \\ \text { S3 } & \text { N-n-Propylbenzene-sulfonamide } \\ \text { NBBS } & \text { N-n-Butylbenzene-sulfonamide } \\ \text { S4 } & \text { N-Geranylbenzene-sulfonamide } \\ \text { S5 } & \text { N-n-Butyl-4-Toluene-sulfonamide } \\ \text { S6 } & \text { N-n-Butyl-4-Fluorbenzene-sulfonamide } \\ \text { S7 } & \text { N-2-Hydroxyethylbenzene-sulfonamide } \\ \text { S8 } & \text { N-2-Hydroxyethyl-4-fluorobenzene-sulfonamide } \\ \text { S9 } & \text { N-n-Pentylbenzene-sulfonamide } \\ \text { S10 } & \text { N-n-Butyl-3-trifluormethylbenzene-sulfonamide } \\ \text { S11 } & \text { N-Geranyl-3-trifluormethylbenzene-sulfonamide } \\ \text { S12 } & \text { N-n-Laurylbenzene-sulfonamide } \\ \text { S13 } & \text { N-n-Butyl-3-trifluormethyl-4-nitrobenzene- } \\ & \text { sulfonamide } \\ \text { S14 } & \text { N-Geranyl-3-trifluormethyl-4-nitrobenzene- } \\ & \text { sulfonamide }\end{array}$

Plasmids

The plasmid pMMTV-luc, which contains a luciferase reporter gene driven by the mouse mammary tumor virus long terminal repeats responsive to androgens, is described in reference [21]. The expression vector for the human AR or AR T877A, pSG-hAR or pSG-hAR T877A and deletions are described in reference [22]. The plasmid $\left(\mathrm{DR}_{4}\right)_{2}$-tk-luc is described in reference [23], for expression of human GR in reference [24] and human TR $\beta$ in reference [25]. Human PR1 and PR2 expression vectors were kindly provided by P. Chambon (Strasbourg, France), human ER $\alpha$ and ER $\beta$ expression vectors by L.C. Murphy (Manitoba, Canada), and the reporter p3ERE-TATA-luc by D.M. Heery (Nottingham, UK).<smiles>[R]NS(=O)(=O)c1ccccc1</smiles>

Reporter assays

CV1 cells were seeded onto 6-well tissue culture plates (Nunc, Roskilde, Denmark) at $1.2 \times 10^{5}$ cells per well and grown in DMEM (Invitrogen) supplemented with $10 \%(\mathrm{v} / \mathrm{v})$ dextran-coated charcoal stripped serum and $1 \%(\mathrm{v} / \mathrm{v})$ penicillin and streptomycin [26]. Six hours later cells were transfected by using the $\mathrm{CaPO}_{4}$ method [22]. The DNA mixture for transfections consisted of $1 \mu \mathrm{g}$ of the appropriated luciferase reporter constructs, $0.2 \mu \mathrm{g}$ of the appropriated mammalian steroid receptor expression vector and $0.2 \mu \mathrm{g}$ of the cytomegalovirus (CMV)-driven $\beta$-galactosidase expressions vector, as internal control for transfection efficiency. For the transient transfection experiments with the ER-receptors, the culture medium of the stock cells was changed to phenol-red-free DMEM (Invitrogen) supplemented with $10 \%(\mathrm{v} / \mathrm{v})$ dextran-coated charcoal stripped serum, $1 \%(\mathrm{v} / \mathrm{v})$ glutamine, $1 \%(\mathrm{v} / \mathrm{v})$ sodium pyruvate and $1 \%(\mathrm{v} / \mathrm{v})$ penicillin-streptomycin. After 7 days, cells were seeded into six-well plates at $1.5 \times 10^{5}$ per well. Twenty-four hours later cells were transfected by using the $\mathrm{CaPO}_{4}$ method [22] with $2 \mu \mathrm{g}$ reporter plasmid, $0.2 \mu \mathrm{g}$ receptor expressions vector and $0.2 \mu \mathrm{g}$ of the cytomegalovirus (CMV)-driven $\beta$-galactosidase for normalization. After $14 \mathrm{~h}$ media were replaced either with or without the addition of the appropriate hormones together with the indicated compounds. After additional $48 \mathrm{~h}$ cells were harvested and assayed for luciferase and $\beta$-galactosidase activity. All transfection assays shown were performed in duplicate and were repeated at least twice.

\section{Cell growth assays}

Human prostate carcinoma LNCaP cells [27] were cultured in RPMI-1640 medium (Invitrogen), supplemented with 10\% $(\mathrm{v} / \mathrm{v})$ fetal calf serum (FCS) (Invitrogen), 1\% (v/v) penicillin and streptomycin (Invitrogen), 1\% (v/v) L-glutamin 
(Invitrogen), 1\% (v/v) sodium pyruvate (Sigma). PC3, PC3ARwt were kindly provided by Dr. A. Cato, Karlsruhe, Germany [28] and were cultured in DMEM supplemented with $10 \%(\mathrm{v} / \mathrm{v}) \mathrm{FCS}, 1 \%(\mathrm{v} / \mathrm{v})$ penicillin and streptomycin and $1 \%(\mathrm{v} / \mathrm{v})$ L-glutamin. PC3-ARwt medium was supplemented with $600 \mu \mathrm{g} / \mathrm{ml}$ geneticin (Invitrogen). C4-2 cells [29] were cultured in DMEM supplemented with $10 \%(\mathrm{v} / \mathrm{v})$ FCS, 20\% F12 (Sigma), $5 \mu \mathrm{g} / \mathrm{ml}$ Insulin, $13.6 \mathrm{pg} / \mathrm{ml}$ T3 (Sigma), $5 \mu \mathrm{g} / \mathrm{ml}$ apotransferrin (Sigma), $0.25 \mu \mathrm{g} / \mathrm{ml}$ Biotin (Sigma), 1\% (v/v) penicillin and streptomycin. For cell growth assays, cells were seeded onto 24-well tissue culture plates (Nunc, Roskilde, Denmark) at $5 \times$ $10^{3}$ cells per well in appropriated medium in triplicates containing 5\% FCS. On day 2, cells were fed with fresh medium and treated with ethanol/DMSO or with the indicated hormones or compounds. Every second day the media was replaced with fresh media together with freshly added compounds. The cells were trypsinized and counted using a counting cell chamber (Double Neubauer, Brand, Germany) at the indicated times.

\section{Nuclear extract preparation}

When LNCaP cells reached 50\% confluency, they were washed three times in PBS and the medium was replaced by RPMI-medium supplemented with $2 \%(\mathrm{v} / \mathrm{v})$ charcoal-dextran-stripped FCS. After 3 days of cultivation the cells were treated with the indicated hormones for $1 \mathrm{~h}$.

For extract preparation the cells were washed twice with ice cold PBS, were harvested with $1 \mathrm{ml}$ PBS and centrifuged at $1,000 \mathrm{~g}$ for $5 \mathrm{~min}$ at $4^{\circ} \mathrm{C}$. The cell pellet was resuspended in three volumes of hypotonic buffer $\mathrm{A}$ (20 mM HEPES, pH 7.9, 10\% glycerol, 0.2\% Nonidet P-40, $10 \mathrm{mM} \mathrm{KCl,} 1 \mathrm{mM}$ EDTA, 0.1 mM PMSF, $1 \mathrm{mM}$ DTT) for $7 \mathrm{~min}$ on ice followed by centrifugation at $3,000 \mathrm{~g}$ for $10 \mathrm{~min}$ at $4^{\circ} \mathrm{C}$. The cytoplasmatic supernatant was removed and the nuclei pellet resuspended in two volumes buffer B (420 mM NaCl, 20 mM HEPES, pH 7.9, $10 \mathrm{mM} \mathrm{KCl}, 1 \mathrm{mM}$ EDTA, $0.1 \mathrm{mM}$ PMSF), followed by rotational incubation for $40 \mathrm{~min}$ at $4{ }^{\circ} \mathrm{C}$. To remove cell debris, the extract was centrifuged at $12,000 \mathrm{~g}$ for $15 \mathrm{~min}$ at $4^{\circ} \mathrm{C}$. The supernatant was transferred into a new tube and diluted with three volumes of buffer $\mathrm{C}(10 \mathrm{mM}$ $\mathrm{KCl}, 20 \mathrm{mM}$ HEPES, pH 7.9, $1 \mathrm{mM}$ EDTA, $0.1 \mathrm{mM}$ PMSF). The cytoplasmic and nuclear extracts were separated on SDS-PAGE and blotted onto a PVDFmembrane (Millipore). Western blot analysis was performed by using a mouse anti-AR antibody (F39.4.1, BioGenex Laboratories) and the enhanced chemiluminescence detection method (Amersham Pharmacia Biotech). The rabbit anti-GAPDH antibody was obtained from abcam (ab9485).
Whole cell binding assay [30]

COS-7 cell were maintained in DMEM, supplemented with $10 \% \mathrm{FCS}, 1 \%(\mathrm{v} / \mathrm{v})$ penicillin and streptomycin in a humidified $5 \% \mathrm{CO}_{2}$ incubator. Cells were seeded into 24-well tissue culture plates (Nunc, Roskilde, Denmark) at $5 \times 10^{4}$ cells per well and grown in phenol-red-free DMEM supplemented with dextran-coated charcoal-stripped serum (5\%). On day 2, cells were transfected (GeneJuice Transfection reagent, Novagen) with $0.75 \mu \mathrm{g}$ pSG5-flagwtAR expression vector, in accordance with the manufacturer's instructions. On day 4, the cells were incubated for $90 \mathrm{~min}$ at $37^{\circ} \mathrm{C}$ with $1 \mathrm{nM}\left[\mathrm{H}^{3}\right]$ mibolerone in the absence and presence of an increasing concentration of either unlabelled mibolerone or NBBS. Working on ice, cells were washed three times with ice-cold $1 \times$ PBS for $15 \mathrm{~min}$. Cells were then lysed with $200 \mu \mathrm{l} 1 \times$ passive lysis buffer (Promega). Lysates were briefly centrifuged and total binding was determined for $150 \mu \mathrm{l}$ of cellular extract by scintillation counting. Non-specific binding was determined as the counts obtained when cells were incubated with $1 \mathrm{nM}\left[\mathrm{H}^{3}\right]$ mibolerone in the presence of $10,000 \times$ unlabelled mibolerone. Specific bound mibolerone was calculated as the difference between total and non-specific binding. The reported values are averages of three independent assays, with each condition performed in triplicate. Data was plotted as percentage $\left[\mathrm{H}^{3}\right]$ mibolerone specifically bound.

\section{Protein detection}

$25 \times 10^{3}$ LNCaP cells were seeded into RPMI medium containing 5\% FCS. After $24 \mathrm{~h}$ cells were incubated with the indicated compounds at $37^{\circ} \mathrm{C}$ for additionally 3 days or 7 days. Proteins were extracted by scrapping cells in ice cold PBS and pelleting cells by centrifugation at $1,000 \mathrm{~g}$ for $5 \mathrm{~min}$ at $4^{\circ} \mathrm{C}$. The cell pellet was resuspended in $500 \mu \mathrm{l}$ NP-40 lysis-buffer (0.1\% SDS, 1\% NP-40, $50 \mathrm{mM}$ Tris, $\mathrm{pH} 8,150 \mathrm{mM} \mathrm{NaCl}, 5 \mathrm{mM}$ ETDA, $1 \mathrm{mM}$ PMSF). The lysis was followed by 3 cycles of freeze (with liquid $\mathrm{N}_{2}$ ) and thaw $\left(37^{\circ} \mathrm{C}\right)$. The cell debris were removed by centrifugation at $12,000 \mathrm{~g}$ for $15 \mathrm{~min}$ at $4^{\circ} \mathrm{C}$. Equal amounts of protein $(10 \mu \mathrm{g})$ were separated on SDS-PAGE and blotted onto a PVDF-membrane (Millipore). Western blot analysis was performed by using a mouse anti-AR antibody (F39.4.1, BioGenex Laboratories) and the enhanced chemiluminescence detection method (Amersham Pharmacia Biotech).

For GFP-AR detection HeLa cells were grown in DMEM with 10\% heat-inactivated FCS. Transfection experiments were performed using the $\mathrm{CaPO}_{4}$ method as described previously [26]. Cells with $20 \%$ confluency were seeded out in $10 \mathrm{~cm}$ dishes using DMEM supplemented 
with $10 \%$ charcoal-stripped FCS and transiently transfected $24 \mathrm{~h}$ later with $10 \mu \mathrm{g}$ of the GFP-hAR expression plasmid (a generous gift from Dr. O. Jänne, University of Helsinki, Finland) together with $5 \mu \mathrm{g}$ calf thymus DNA. After 1 day the cells were washed twice with PBS and fresh medium containing 10\% charcoal-stripped FCS was added. $48 \mathrm{~h}$ after transfection the cells were treated with NBBS $\left(10^{-4} \mathrm{M}\right)$ and/or R1881 (Methyltrienolone) $\left(10^{-10} \mathrm{M}\right)$ for $1 \mathrm{~h}$. Cells were then analyzed using a fluorescence microscopy with a FITC filter. As control, cell morphology of the same cells is shown by phase contrast. Sets of $2-3 \times 100$ cells were counted and the cytosolic/nuclear distribution of GFP fluorescence was determined. The error represents deviation of the mean.

\section{Real time RT-PCR}

The real time RT-PCR (qRT-PCR) was performed essentially as described previously [31] with specific primers for detection of PSA mRNA and beta-actin mRNA for normalization. As modifications $1.28 \times 10^{6}$ cells were seeded out directly in media containing $10 \%$ charcoal stripped FCS. After 2 days cells were treated with $100 \mu \mathrm{M}$ NBBS or solvent (ethanol) or androgen (R1881) was added to a final concentration of $50 \mathrm{pM}$.

\section{Results}

NBBS as a receptor specific androgen antagonist

Previously, we have described the isolation of NBBS from the methylene chloride extract of Pygeum africanum [20]. NBBS exhibits antiandrogenic activity inhibiting ligandactivated human AR (Fig. 1) using transient transfection assays expressing human AR in CV1 cells with cotransfection of MMTV-luc, a well-known AR responsive promoter [21]. To test specifically for the AR-mediated transactivation, CV1 cells were used, which lack the expression of endogenous AR, GR and PR that all bind to and mediate transactivation from the same response elements. As control, cells were treated with the solvent itself and compared to untreated. The data suggest that NBBS inhibits the ligand-induced transactivation of human AR.

To test for the potency of NBBS, on one hand a concentration series of androgen agonists and on the other hand a concentration series of NBBS was applied. Treatment of transfected cells with a concentration series of the natural androgen dihydrotestosterone (DHT) lead to significant hormone-dependent induction of the luciferase reporter at $0.5 \mathrm{nM}$ DHT and strong induction at $10 \mathrm{nM}$ of DHT (Fig. 2a). Addition of NBBS $(100 \mu \mathrm{M})$ in the absence of DHT did not affect the reporter activity. In line with that

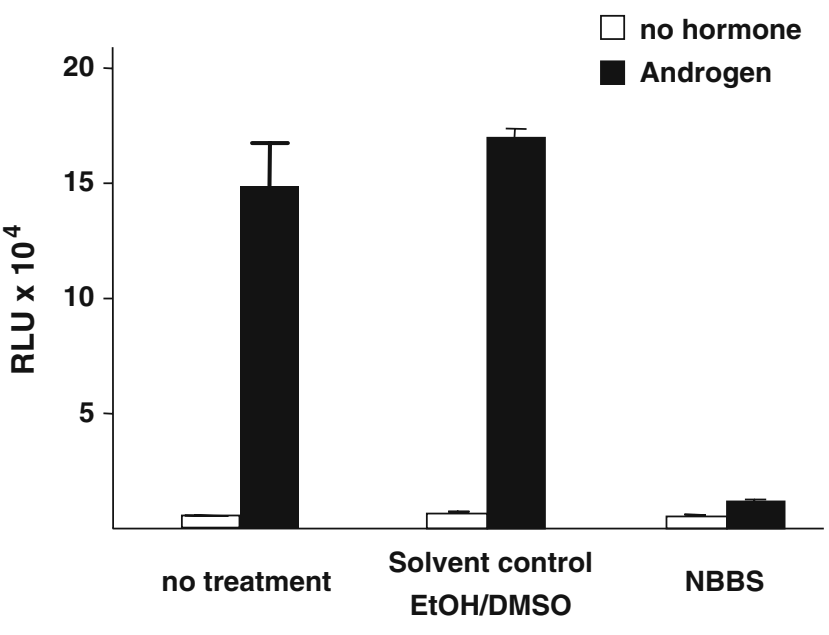

Fig. 1 Inhibition of androgen activity by NBBS isolated from Pygeum africanum extracts. CV1 cells, lacking functional endogenous AR were transfected with the expression vector for human $A R$ and the reporter MMTV-luciferase either untreated (white bars) or treated with the androgen methyltrienolone (R1881; $3 \times 10^{-10} \mathrm{M}$ final concentration; black bars). Luciferase values obtained were normalized to the cotransfected internal control and indicated as relative light units (RLU). In addition cells were treated with NBBS $(100 \mu \mathrm{M})$, dissolved in ethanol/DMSO (1:1) or with this solvent alone (Solvent control). As further controls, cells were tested without solvent treatment

cell viability assays NBBS did not reveal cytotoxicity (data not shown). In the presence of DHT, however, addition of $100 \mu \mathrm{M}$ of NBBS potently inhibited DHT-induced (10 nM) AR-mediated transactivation.

Since DHT undergoes rapid turnover and the degradation products may give side-effects, we have also treated cells with methyltrienolone (R1881), known to be a very potent agonist ligand for human AR, leading to hormonedependent induction of the reporter. One reason for that is the higher stability of R1881 compared to DHT, which can be easily degraded in cells [32]. Consequently, R1881 treatment lead to a ligand-induced activation of the reporter at lower concentrations as observed with DHT (Fig. 2b). At low concentrations of R1881, in the range of $10 \mathrm{pM}$, NBBS inhibited potently the AR mediated transactivation. At concentrations of $0.1 \mathrm{nM}$ of R1881, NBBS $(100 \mu \mathrm{M})$ inhibited significantly ligand-activated $A R$, whereas at $0.5 \mathrm{nM}$ of R1881 NBBS was ineffective in repressing AR transactivation (Fig. 2b) suggesting a potential competition between R1881 and NBBS. Using a concentration series of NBBS in the presence of 10 pM R1881 revealed that NBBS potently inhibits liganded human AR at $10 \mu \mathrm{M}$ and $100 \mu \mathrm{M}$ (Fig. 3a).

Although the hydrophobic DHT and R1881 are thought to easily pass the cell membrane [33], the permeability and thus the intracellular concentration of the more hydrophilic NBBS is unclear. Therefore, on molecular level the efficacy of NBBS may be higher. Taken together, our data strongly 
Fig. 2 NBBS inhibits the transcriptional activity of human AR activated by DHT or the synthetic agonist R1881. Cells were tested in the AR activity based assay described in Fig. 1 with a concentration series of each androgen together with $100 \mu \mathrm{M}$ NBBS (black bars) or with the solvent control (white bars). a Human AR was activated by the natural hormone dihydrotestosterone (DHT) or $\mathbf{b}$ by methyltrienolone (R1881) at the indicated concentrations

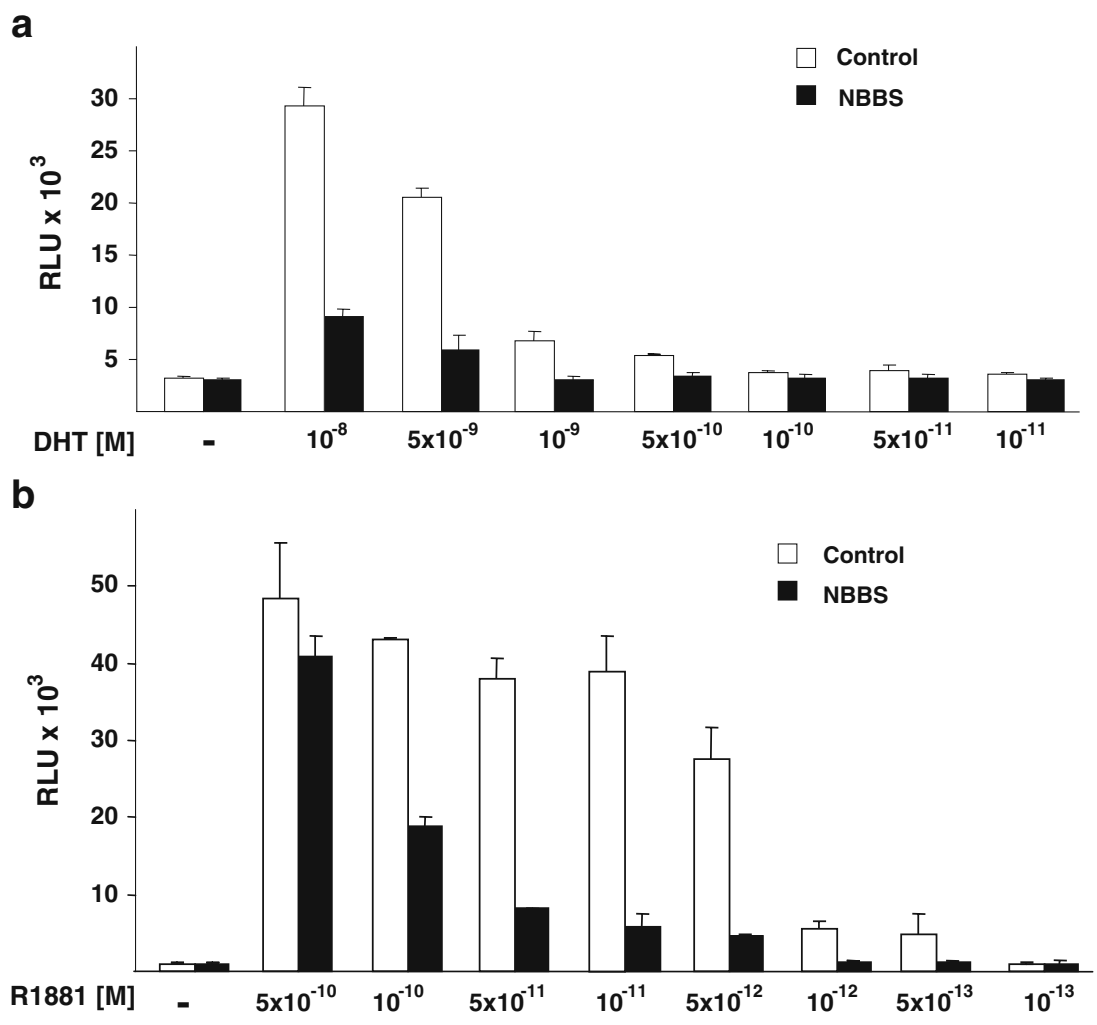

suggest that NBBS is able to repress the transactivation of human AR.

To reveal whether NBBS inhibits the transactivation of the endogenously expressed AR in human PCa cells we analyzed the endogenous expression of the prostate specific antigen (PSA) a diagnostic marker for $\mathrm{PCa}$ and a direct target gene of the AR using qRT-PCR normalized to beta-actin expression. In line with our data, treatment of both $\mathrm{LNCaP}$ and C4-2 PCa cells with $100 \mu \mathrm{M}$ NBBS resulted in inhibition of androgen-induced PSA expression (Fig. 3b).

To analyze the receptor specificity of NBBS various members of the nuclear hormone receptor superfamily were used for reporter assays (Fig. 4). The closely related members of $\mathrm{AR}$ are the GR and PR for which the MMTV-reporter is also a suitable responsive reporter. CV1 cells were chosen since they lack functional GR, PR, ERs and thyroid hormone receptors (TR). $1 \mu \mathrm{M}, 10 \mu \mathrm{M}$ and $100 \mu \mathrm{M}$ of NBBS did not affect the glucocorticoidinduced transactivation of human GR (Fig. 4a and supplemental data). We decreased hormone levels to an extent to still be able to obtain significant hormone-induced transactivation. In case of human PR both forms were tested, the PR-B form with a more potent transactivation function and the PR-A form, which is generated by an internal translation start site. NBBS inhibited the progesterone-induced transactivation of the PR-B form at $0.1 \mathrm{nM}$ as well as the PR-A form (Fig. $4 \mathrm{~b}$ and supplemental data). Using the human TR $\beta$, with a TR responsive reporter addition of NBBS did not affect significantly the thyroid hormone (T3) induced transactivation of TR at various thyroid hormone concentrations (Fig. 4c and supplemental data). Similarly, NBBS treatment seems not affect either of the estrogen receptors, $\mathrm{ER} \alpha$ and ER $\beta$ (Fig. 4d). This indicates that NBBS has a strong preference for the AR and PR.

\section{Growth inhibition of human PCa cells by NBBS}

The growth of prostate cells and PCa cells is initially dependent on androgens. To test whether the androgen antagonism of NBBS affects cell growth we used the human androgen-dependent $\mathrm{PCa}$ cell line LNCaP. Equal numbers of $\mathrm{LNCaP}$ cells were seeded out and were treated with $10 \mu \mathrm{M}$ and $100 \mu \mathrm{M}$ of NBBS as well as the known AR antagonist hydroxyflutamide (OH-F) in $5 \%$ normal serum that is known to naturally contain androgens. Already at day 5, cells treated with $100 \mu \mathrm{M}$ NBBS exhibited a significant reduced growth (Fig. 5a). The growth inhibitory effect was more prominent at day 8 of treatment. In the presence of $10 \mu \mathrm{M}$ NBBS the LNCaP cells revealed a reduced growth at day 8 , whereas treatment with $\mathrm{OH}-\mathrm{F}$ did not show growth inhibition. This may be due to the known fact that LNCaP cells 
Fig. 3 NBBS inhibits ligand activated human AR and PSA expression in human PCa cell lines. a Increasing concentrations of NBBS were tested for its ability to inhibit methyltrienolone $\left(10^{-11} \mathrm{M}\right)$ activated human AR with the experimental setup described in methods and Fig. 1. As control cells were treated with the solvent alone. b NBBS $\left(10^{-4} \mathrm{M}\right)$ inhibits the PSA expression in human PCa cell lines.

Endogenously expressed PSA mRNA levels were detected using qRT-PCR and values were normalized to the expression of beta-actin. Left panel: qRT-PCR with androgen-dependent growing LNCaP cells. Right panel: qRT-PCR with androgen-independent growing C4-2 cells

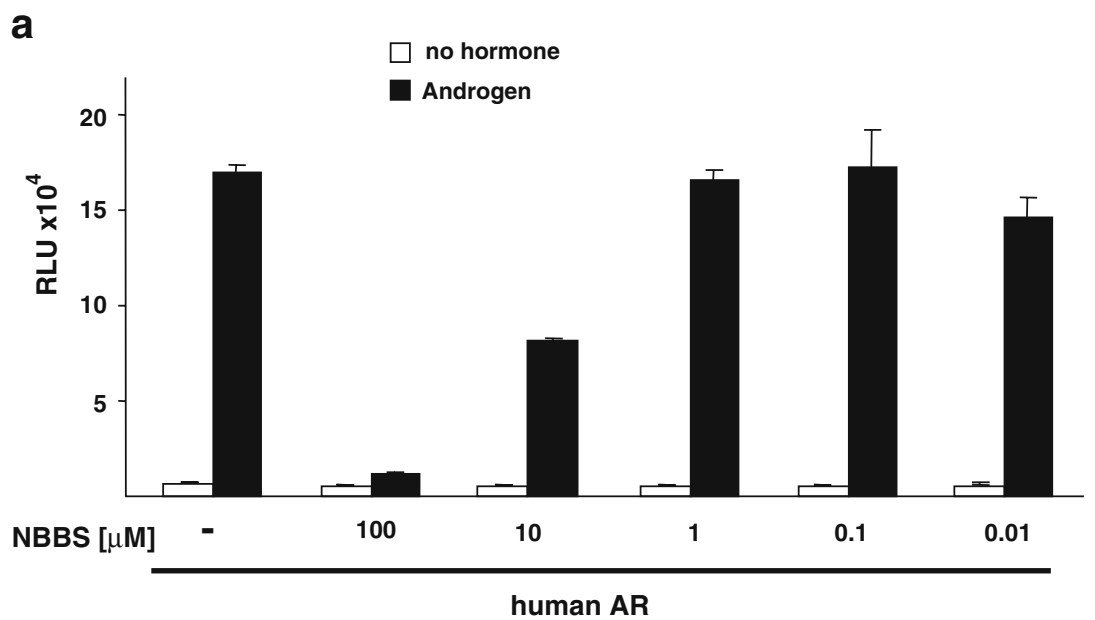

b LNCaP

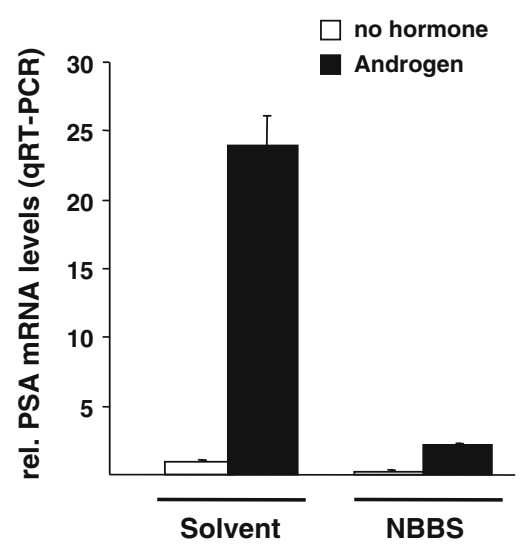
C4-2

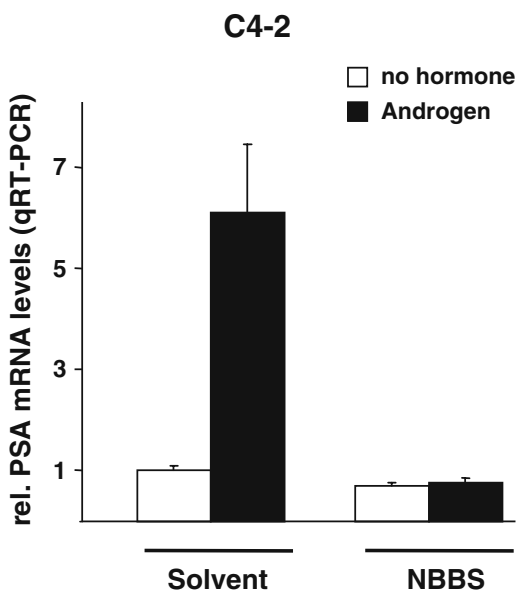

have a point mutation in the hormone-binding domain (HBD) of the human AR (T877A) that prevents OH-F for being an antiandrogen rather a potent agonist in these cells $[13,15]$.

Furthermore, we addressed the question whether the androgen-independently growing C4-2 PCa cell line is also growth reduced by NBBS treatment (Fig. 5b). Interestingly, treatment of C4-2 cells with NBBS potently inhibits the growth also of these cells to a similar extent as was observed for LNCaP cells. This indicates that NBBS is able to inhibit androgen-independent PCa cells.

To verify this finding, the androgen-independently growing human PCa PC3-ARwt cells were used expressing the wild-type human AR protein from a stable expression vector integrate [28]. Similarly, the growth of these cells was inhibited with NBBS treatment (Fig. 5c). As control the parental PC3 cells, that lack the expression of wild-type AR, were tested for the efficacy of NBBS to affect their proliferation. Here notably, applying NBBS did not significantly affect the growth of PC3 cells (Fig. 5d). This suggests that NBBS inhibits specifically growth of PCa cells expressing the mutant or wild-type AR further supporting its role as an AR-antagonist.
To test whether NBBS might affect the stability of AR, Western blot analyses were performed with LNCaP cells treated for 3 days or 7 days without (control) or with NBBS (supplemental data) with anti-AR antibodies. Interestingly, neither treatment with $10 \mu \mathrm{M}$ nor $100 \mu \mathrm{M}$ resulted in a reduced amount of AR (supplemental data) suggesting that NBBS-mediated inhibition of AR transactivation is not regulated through AR protein stability.

Taken together, these findings indicate that inhibition of proliferation by NBBS is mediated through human AR and is effective also for androgen-independently growing $\mathrm{PCa}$ cells. In addition these data suggest that the inhibition of proliferation of NBBS is also effective for cells expressing the AR-T877A mutant, which is not significantly inhibited by OH-F [13-15].

NBBS binds to AR and inhibits its nuclear translocation

To analyze the underlying mechanism of NBBS-mediated inhibition of $\mathrm{AR}$ transactivation we first employed $\mathrm{AR}$ deletion mutants. Since both LNCaP and C4-2 cells were inhibited in growth and both cell types harbor the mutant AR T877A we analyzed whether the transactivation of this 
a

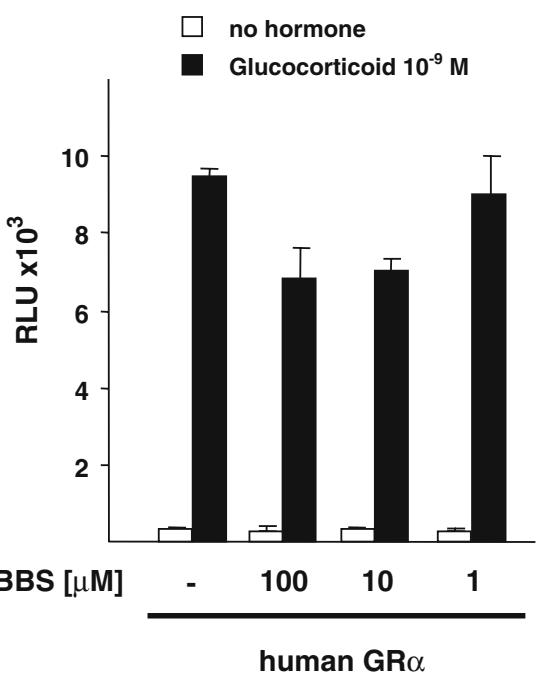

b

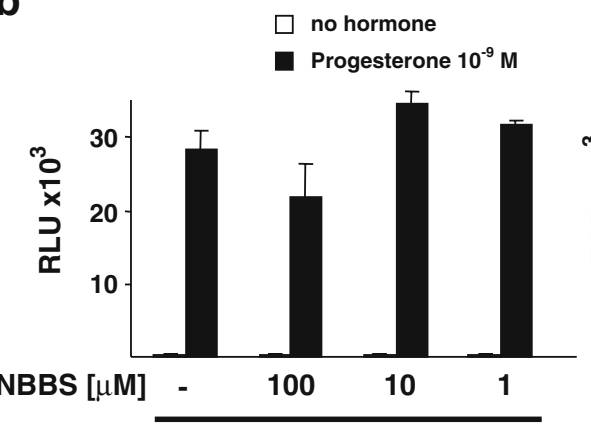

human PR B-form

C

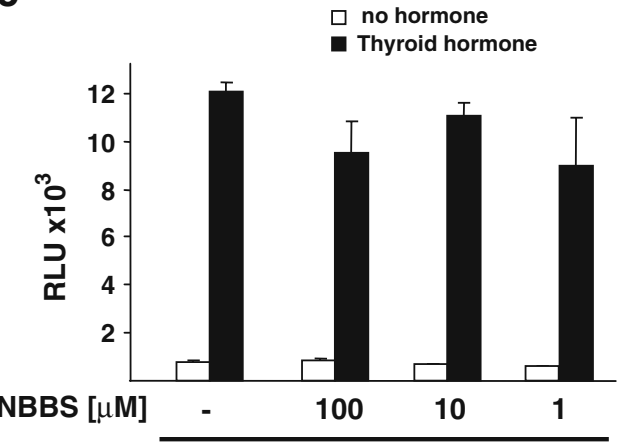

human TR $\beta$

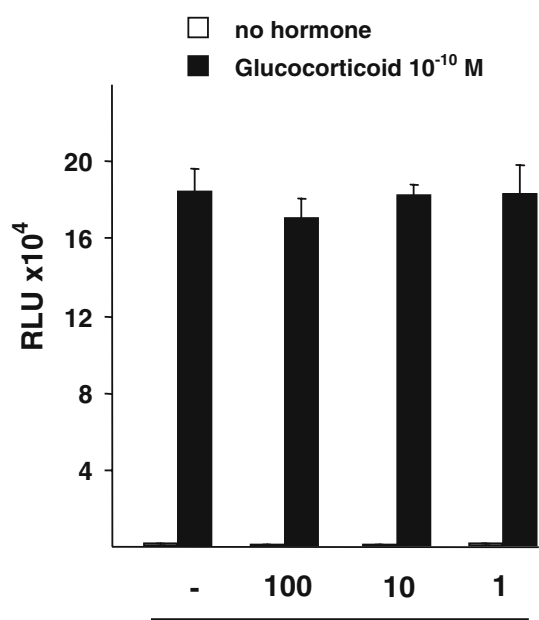

human GR $\alpha$

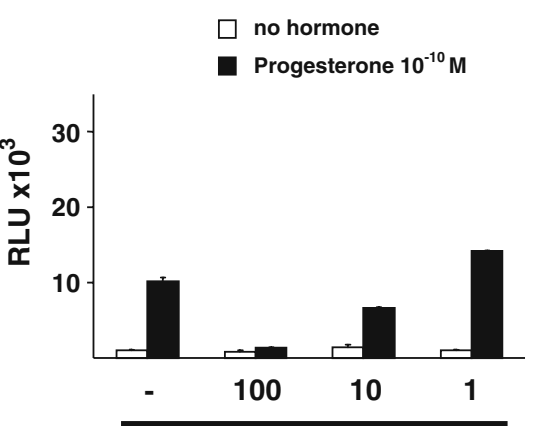

human PR B-form

d

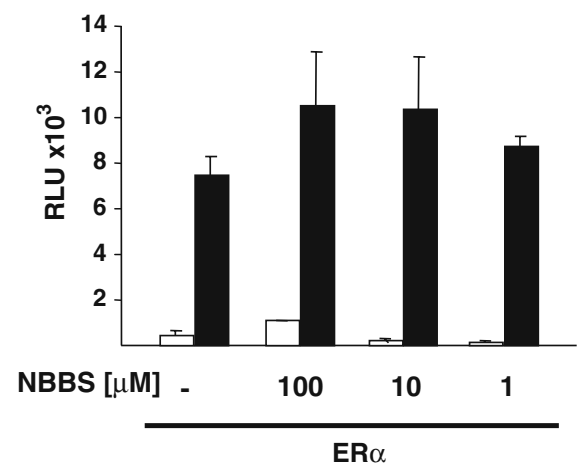

$\square$ no hormone

Estradiol

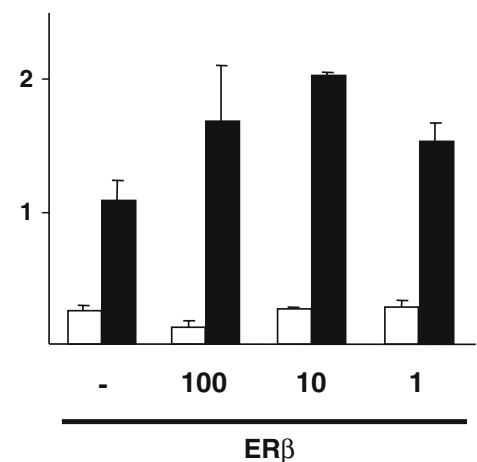

Fig. 4 NBBS inhibits specifically human AR and PR. Other members of the nuclear hormone receptor superfamiliy were and PR selected to test their inhibition by NBBS. The human glucocorticoid receptor (hGR), the human progesterone receptor (PR-B), and the human thyroid hormone receptor $\beta$ (human TR $\beta$ ) were tested with the appropriate reporters (MMTV-luciferase for hGR, PR-B, and $\mathrm{p}\left(\mathrm{DR}_{4}\right)_{2^{-}}$ tk-Luc for TR, respectively), whereas pVit3x-TAT-Luc for both

AR mutant can be suppressed by NBBS. Cotransfection experiments in CV1 cells revealed that the mutant AR T887A-mediated transactivation is also repressed by NBBS (Fig. 6a) suggesting that NBBS acts distinct from the
Estrogen receptors $E R \alpha$ and $E R \beta$ in $C V 1$ cells, lacking functional endogenous GR, PR, ER or TR. Increasing concentrations of NBBS were tested for inhibition, ER of glucocorticoid (dexamethasone at $10^{-9} \mathrm{M}$ and $10^{-10} \mathrm{M}$ ) activated hGR (a), for PR-B activated with progesterone $\left(10^{-9} \mathrm{M}\right.$ and $\left.10^{-10} \mathrm{M}\right)(\mathbf{b})$, for TR $\beta$ activated with thyroid hormone $\left(10^{-9} \mathrm{M}\right)(\mathbf{c})$ and estradiol $\left(10^{-9} \mathrm{M}\right)$ activated ER (d). As control cells were treated with the solvent alone antagonist OH-F, which activates this AR mutant [13-15] (and own observation).

To reveal whether the HBD of AR is necessary for NBBS mediated suppression AR-deletions were employed 
a

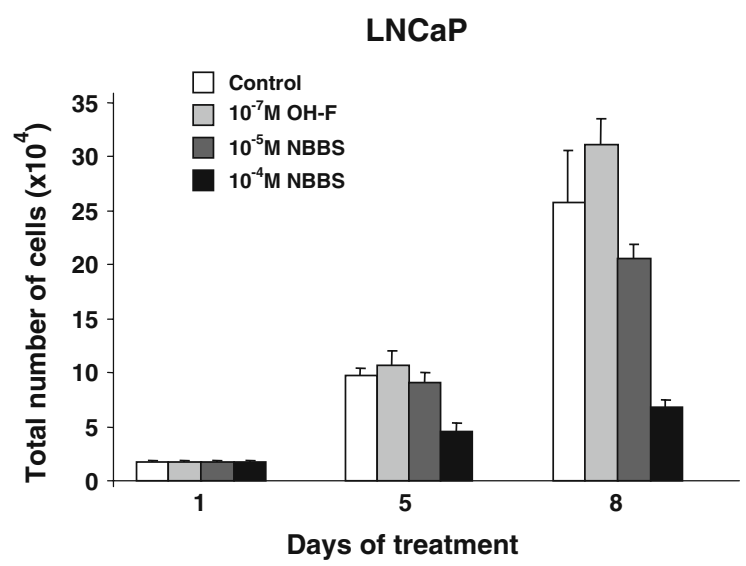

b

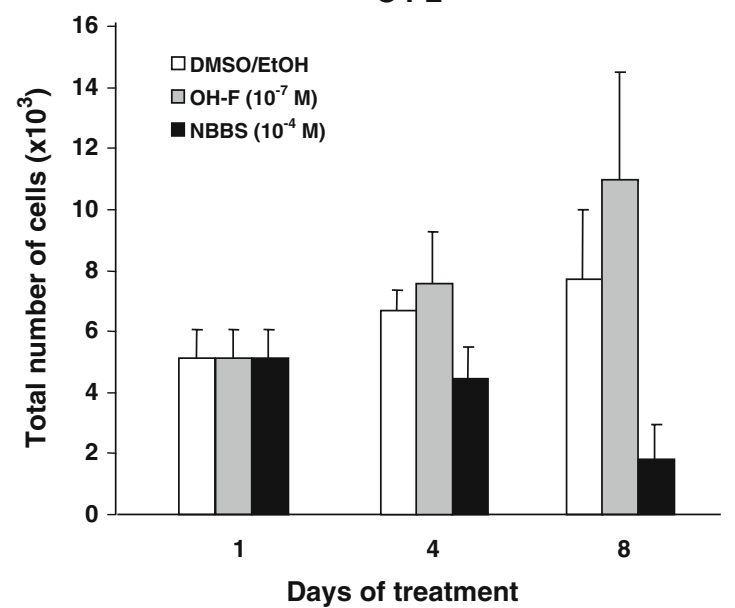

Fig. 5 NBBS inhibits growth of the prostate cancer cell line LNCaP, C4-2 and PC3-ARwt. Two different concentrations of NBBS $(10 \mu \mathrm{M}$ and $100 \mu \mathrm{M}$ ) were tested for the ability to influence growth of the model human PCa cell line LNCaP (a), $100 \mu \mathrm{M}$ of NBBS for C4-2 (b) and PC3-AR (c) cells. PC3 cells lacking AR expression were used as

(Fig. 6a, right panel). Deletion of the HBD leads to a hormone-independent transactivation of AR [22], which however, cannot be suppressed by NBBS, indicating that the HBD is required for NBBS-mediated antagonism. Deletion of the first 171 amino acids of the AR resulted in reduced transactivation that was inhibited by NBBS (Fig. 6a, left panel). The deletion of the entire N-terminus is transcriptional inactive, which is in line with previous observations that the major transactivation domain is localized in the AR amino-terminus [22, 34-36] and thus NBBS is unable to inhibit. These data suggest that the HBD is required for the NBBS mediated inhibition of $\mathrm{AR}$ transactivation.

Based on the requirement of the AR HBD for NBBS action we wanted to determine whether NBBS is able to compete for hormone binding. Therefore, competitive
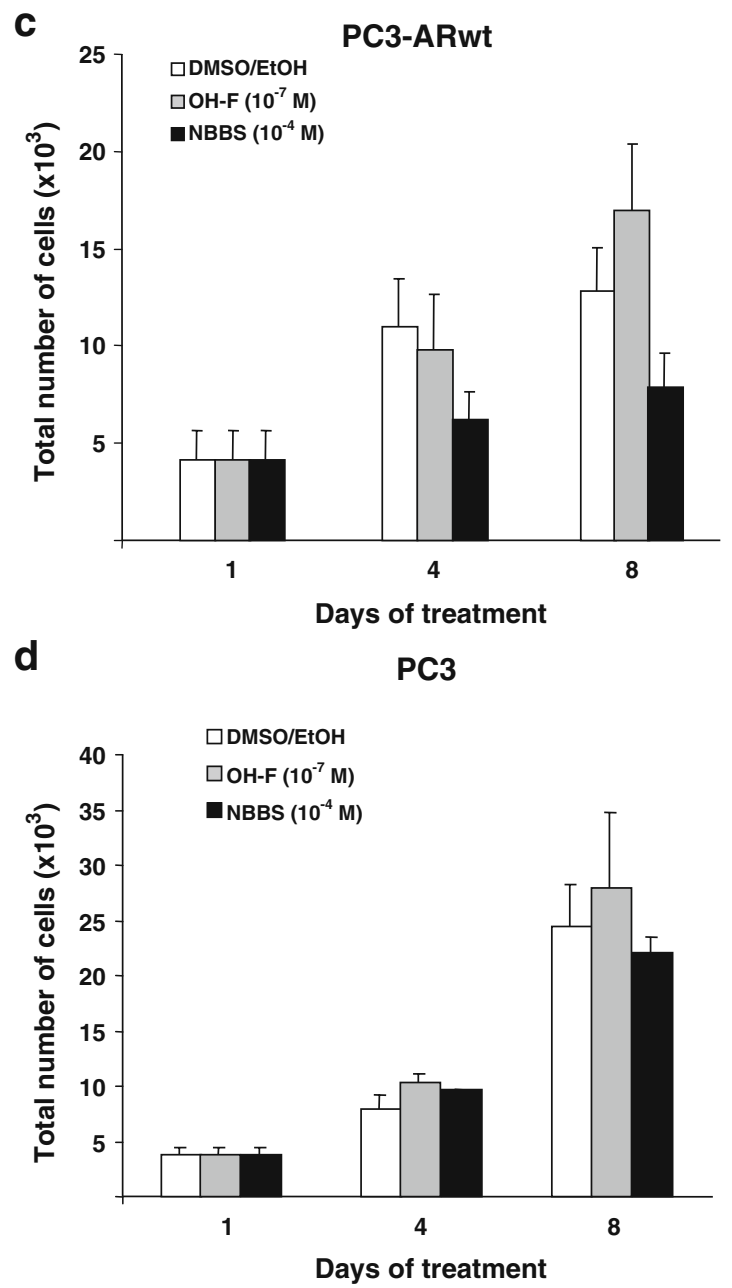

control (d). Equal amounts of cells were seeded out and were either treated with NBBS, the known androgen antagonist hydroxyflutamide $(\mathrm{OH}-\mathrm{F})$, or solvent control. The number of cells was counted at the indicated days

whole cell binding assays with AR and radioactive labeled mibolerone were performed (Fig. 6b). Mibolerone is known to bind to the AR HBD hormone pocket. Replacement of mibolerone leads to a reduced amount of radioactive material bound to AR. As control, unlabeled mibolerone was used. Treatment of AR with increasing amount of NBBS indeed resulted in a decrease of mibolerone binding (Fig. 6b) at concentrations that were also active in the previous experiments (Figs. 3 and 6a). This suggests that NBBS binds to the HBD of AR and confirms our previous results.

Further, to analyze for NBBS-mediated antagonism the involvement of corepressors were analyzed. Androgen antagonists are known to recruit corepressors for suppression of AR mediated transactivation [22, 37-39]. However, we did not find corepressor interaction with NBBS 
treatment using the classical modified mammalian twohybrid system employing SMRT, NCoR and Alien $([22,40]$ and data not shown). Then we addressed another hypothetical possibility to repress AR transactivation, which is the inhibition of nuclear translocation [31]. For that purpose endogenously expressed human AR was analyzed by preparing cytosolic and nuclear fractions from the human androgen-dependent $\mathrm{PCa}$ cell line $\mathrm{LNCaP}$ treated with R1881 and without or with NBBS. Western analysis was used to detect the localization of AR (Fig. 6c). Without R1881 treatment the majority of AR showed cytosolic localization and treatment with NBBS suggest no significant changes in the cytosolic-nuclear ratio. Treatment of cells with R1881 resulted in detection of the majority of $\mathrm{AR}$ in the nuclear fraction. Interestingly, combined treatment of R1881 together with NBBS revealed that the AR changed the ration of being more cytosolic and less nuclear compared to agonist treatment alone (Fig. 6c).

To further verify this finding the human AR was fused to GFP. The GFP-AR fusion was expressed in HeLa cells and tested whether NBBS affects the agonist-induced translocation of AR into the nucleus by treating cells with R1881 and without or with NBBS (Fig. 6d). The AR-specific agonist R1881-induced translocation of the GFP-AR fusion into the nucleus, however, in combination with NBBS the GFP-AR remained pre-dominantly in the cytoplasm. The statistic analysis of the cytosolic and nuclear ratio of GFP-AR staining further indicates that treatment with NBBS alone does not affect AR translocation but inhibits the agonist-induced translocation (Fig. 6e). Thus, these data indicate that the agonist-induced translocation is inhibited by treatment of cells with NBBS. This further confirms that NBBS inhibits AR translocation into the nucleus.

Thus, our data suggests that the molecular basis of inhibition of AR transactivation by NBBS is to suppress the hormone-induced translocation into the cell nucleus.

NBBS derivatives as potential new antiandrogens

A battery of NBBS derivatives was chemically synthesized to modify the butyl side chain and the benzene ring by substitutions (Fig. 7). These compounds were employed for their ability to act as AR antagonists in the cell culture based assay. To test for potential higher efficient repression of AR-mediated transactivation we compared the efficacy of each compound at $10 \mu \mathrm{M}$ concentration with that of NBBS (Fig. 8). We used a higher concentration $(3 \times$ $\left.10^{-10} \mathrm{M}\right)$ of $\mathrm{R} 1881$, at which NBBS lacked significant inhibition of AR-mediated transactivation (Fig. $2 b$ and data not shown). The compounds S1-S3 and S5-S8 exhibited no significant antiandrogenic effect. These modifications included either shortening the butyl side chain (S1-S3 and S7) or substitution of the benzene ring at the para-position (S5, S6 and S8). This strongly suggests the importance of the length of the side chain and an unsubstituted benzene ring at the para-position as antiandrogenic compound (Figs. 7a and 8a).

Interestingly, lengthening the side chain by replacing the butyl side chain with a pentyl or a geranyl group (S4 and S9) enhanced the antiandrogenic activity indicating that a hydrophobic side chain is important for androgen antagonistic function. However, further extension of the side chain by introducing a lauryl group (S12; Figs. $7 \mathrm{~b}$ and $8 \mathrm{~b}$ ) weakened the androgen antagonistic potency. This indicates that enhancing the hydrophobicity alone is not sufficient to enhance antiandrogenicity.

Notably, also substitutions at the meta-position of the benzene ring enhanced androgen antagonistic activity (S10, S11, S13 and S14; Figs. 7 and 8). Thus, through generation of NBBS-derivatives enhancing hydrophobicity at the side chain or substitutions at the meta-position of the benzene ring the AR antagonism was potently enhanced suggesting that NBBS can serve as a novel platform to generate new AR antagonists.

To analyze whether derivatives exhibit a similar underlying mechanism as NBBS to inhibit the androgen-induced translocation $\mathrm{AR}$ we performed a similar experimental setup employing GFP-AR. According to NBBS, also the more potent compounds S10 and S11 inhibited the ARmediated translocation (Fig. 8c) suggesting that NBBS derivatives may be a useful tool to inhibit the AR at a step prior its action in the nucleus.

Thus, it may be possible to generate even more potent androgen antagonists based on natural bio-active chemical structures as lead compounds.

\section{Discussion}

In the present study we have characterized the natural compound NBBS as androgen antagonist. NBBS is very effective at $100 \mu \mathrm{M}$ concentration in cell culture systems. It inhibits potently both the transactivation of human AR induced by androgens and the growth of the human LNCaP PCa cells. Due to the hydrophobicity the androgens DHT and R1881 are thought to not require an active process to enter the cytoplasm and to bind to AR [33]. NBBS is more hydrophilic in nature and therefore the mode of cellular uptake may not be comparable. Thus, the concentration of NBBS used for treatment of cells and required for potent inhibition does not necessarily reflect its intracellular concentration. Other natural compounds were shown to require a similar concentration range of action [41-46]. 
a

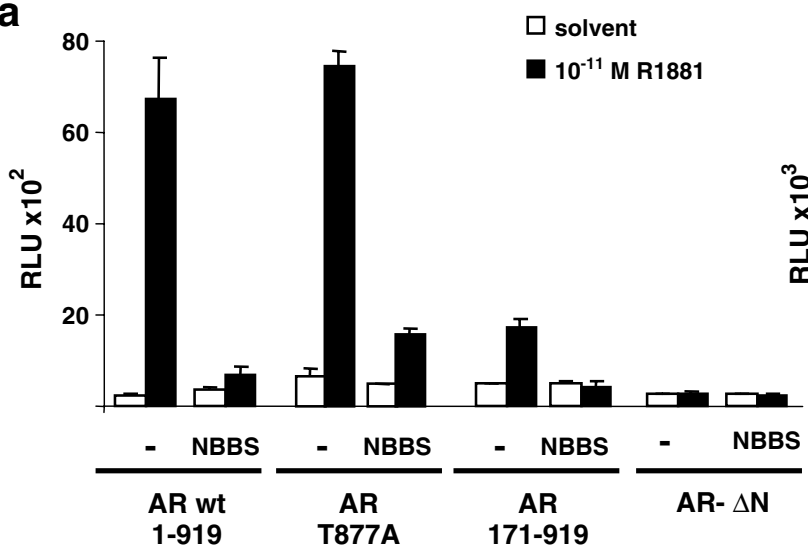

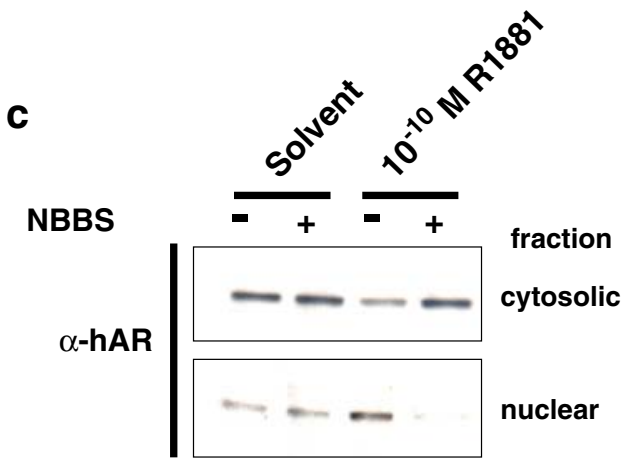

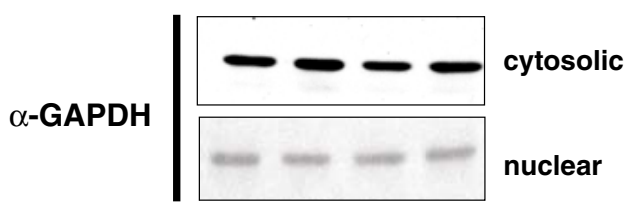

d

GFP-hAR

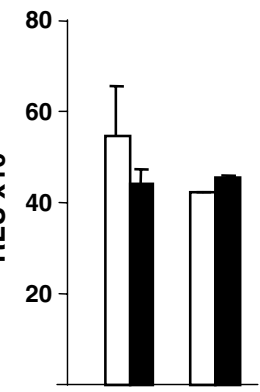

- NBBS

AR- $\triangle$ HBD b

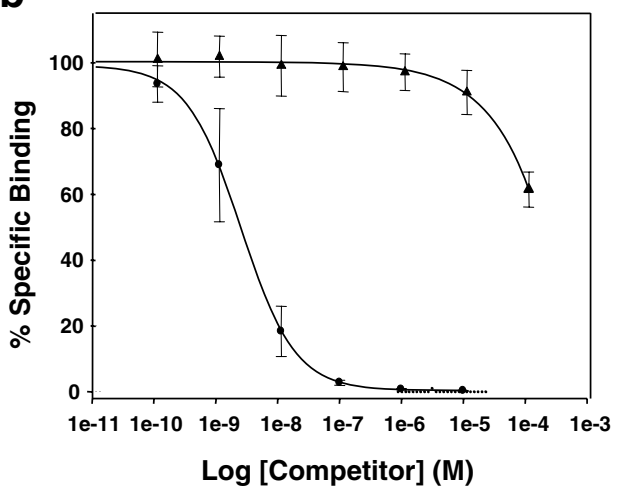

e

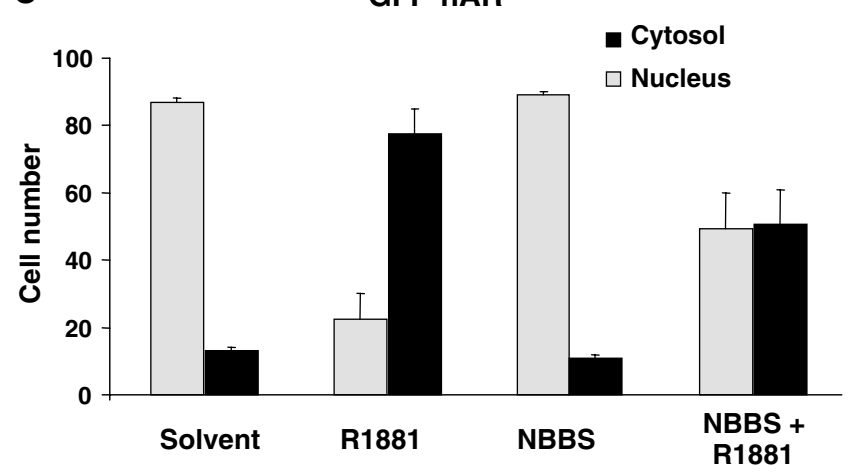

Fig. 6 NBBS binds to the HBD of $A R$ and inhibits nuclear translocation. a NBBS was tested for its ability to repress ARdeletions in CV1 cells. Obtained luciferase units were normalized to the internal LacZ standard. AR 179-919 represents a deletion of the first 178 amino acids. AR $\Delta \mathrm{N}$ lacks the first 504 amino acids, whereas AR $\triangle$ HBD lacks the entire HBD. b Competitive whole cell binding assays were performed using pSG5-flag-wtAR transfected COS-7 cells incubated with $1 \mathrm{nM}\left[{ }^{3} \mathrm{H}\right]$ mibolerone in the absence and presence of increasing concentrations of either unlabelled mibolerone (filled circle) or NBBS (filled triangle) for $90 \mathrm{~min}$. Competition for binding is illustrated by the percent of $\left[{ }^{3} \mathrm{H}\right]$ mibolerone specifically bound to the AR. Results are averages of three independent experiments with each condition in triplicate $( \pm \mathrm{SEM})$. c Nuclear translocation of AR was tested by Western blot analysis of LNCaP cell extracts derived from the cytosolic or nuclear fraction of cells that were treated with or without $0.1 \mathrm{nM}$ R1881 in the absence or presence of NBBS. Detection of GAPDH was used as control. d HeLa cells were transfected with the GFP-AR expression vector. Cells were treated with NBBS $\left(10^{-4} \mathrm{M}\right)$ and/or R1881 $\left(10^{-10} \mathrm{M}\right)$ for $1 \mathrm{~h}$. Unfixed cells were then analyzed using a fluorescence microscopy with a fluorescine isothiocyanate (FITC) filter. As control, cell morphology of the same cells is shown in the lower panel. e The cytosolic/nuclear distribution of GFP fluorescence staining of GFP-AR transfected HeLa cells was determined 
Fig. 7 a and b Chemical structures of NBBS derivatives (S1-S14) used for androgen antagonistic activity tests a<smiles>CNS(=O)(=O)c1ccccc1</smiles><smiles>CCNS(=O)(=O)c1ccccc1</smiles>

S2<smiles>CCCNS(=O)(=O)c1ccccc1</smiles>

S3<smiles>CCCCNS(=O)(=O)c1ccccc1</smiles>

NBBS<smiles>CC(C)=CCC/C(C)=C/CNS(=O)(=O)c1ccccc1</smiles>

S4<smiles>CCCCNS(=O)(=O)c1ccc(C)cc1</smiles>

S5<smiles>CCCCNS(=O)(=O)c1ccc(F)cc1</smiles>

S6<smiles>O=S(=O)(NCCO)c1ccccc1</smiles>

S7<smiles>O=S(=O)(NCCO)c1ccc(F)cc1</smiles>

S8<smiles>CCCCCNS(=O)(=O)c1ccccc1</smiles>

S9

b<smiles>CCCCNS(=O)(=O)c1cccc(C(F)(F)F)c1</smiles>

S10<smiles>CCCCCCCCCCCCNS(=O)(=O)c1ccccc1</smiles>

S12<smiles>CC(C)=CCC/C(C)=C/CNS(=O)(=O)c1ccc([N+](=O)[O-])c(C(F)(F)F)c1</smiles>

S14<smiles>CC(C)=CCC/C(C)=C/CNS(=O)(=O)c1cccc(C(F)(F)F)c1</smiles>

S11<smiles>CCCCNS(=O)(=O)c1ccc([N+](=O)[O-])c(C(F)(F)F)c1</smiles>

S13
Thus, our findings are in line with observations of other groups using natural compounds. Also, it is possible that NBBS may act in concert with other natural compounds that enhance the androgen antagonism and growth inhibition.

Interestingly, NBBS inhibits the growth of the human PCa cell line LNCaP that were derived from lymph node metastasis. These cells express a mutated human AR with the consequences that the androgen antagonist $\mathrm{OH}-\mathrm{F}$ exhibits agonistic activity instead of inhibiting AR [13, 15]. This may be an important molecular mechanism of how therapy resistance by treatment of patients with androgen antagonists may occur. Since NBBS is able to inhibit growth of LNCaP C4-2 and PC3-AR cells it may serve as a tumor inhibitor despite the occurrence of therapy resistance to other androgen antagonists. This may also lead to the conclusion that NBBS might be used in addition to other androgen antagonists or in combination with androgen ablation therapy.

The obtained results suggest that the underlying mechanism of NBBS to inhibit AR transactivation is based on suppression of nuclear translocation of AR. The currently clinically used AR antagonists inhibit AR based on mechanisms such as through recruitment of corepressors or through changing chromatin accessibility [22, 37-39, 47, 48]. The novel mechanism described here may also allow in future understanding better the structural features of $A R$ to undergo nuclear translocation.

In addition, the problem of therapy resistance of $\mathrm{PCa}$ that eventually occurs during $\mathrm{PCa}$ development or selected under cancer therapy, is in great part based on the AR that becomes transcriptionally active despite antagonist treatment. The underlying mechanisms include amplification or mutations of the AR gene leading to mutant ARs that bind in a more promiscuous manner other ligands. Also discussed is the lack of corepressor binding to AR due to activation of signaling pathways such as protein kinase A or membrane tyrosine kinases (her/neu) [5, 22]. Reduced or lack of corepressor binding abrogates AR inhibition by androgen antagonists. A novel mechanism to inhibit AR transactivation, such as by suppressing its nuclear translocation, may allow treatment of patients that developed 
Fig. 8 Compounds S4, S9, S10, S11, S13, and S14 exhibit a higher androgen antagonistic activity compared to NBBS. a and $\mathbf{b}$ Each of the compounds, S1-S14 (see "Materials and methods") were tested for their ability to inhibit ligand activated human AR in CV1 cells and compared with the activity of NBBS at $10 \mu \mathrm{M}$. c The

cytosolic/nuclear distribution of GFP fluorescence staining of

GFP-AR transfected HeLa cells was determined as described in Fig. 6. The data suggest that the NBBS derivatives S10 and S11 inhibit, similarly to NBBS, the androgen-induced translocation of human AR a
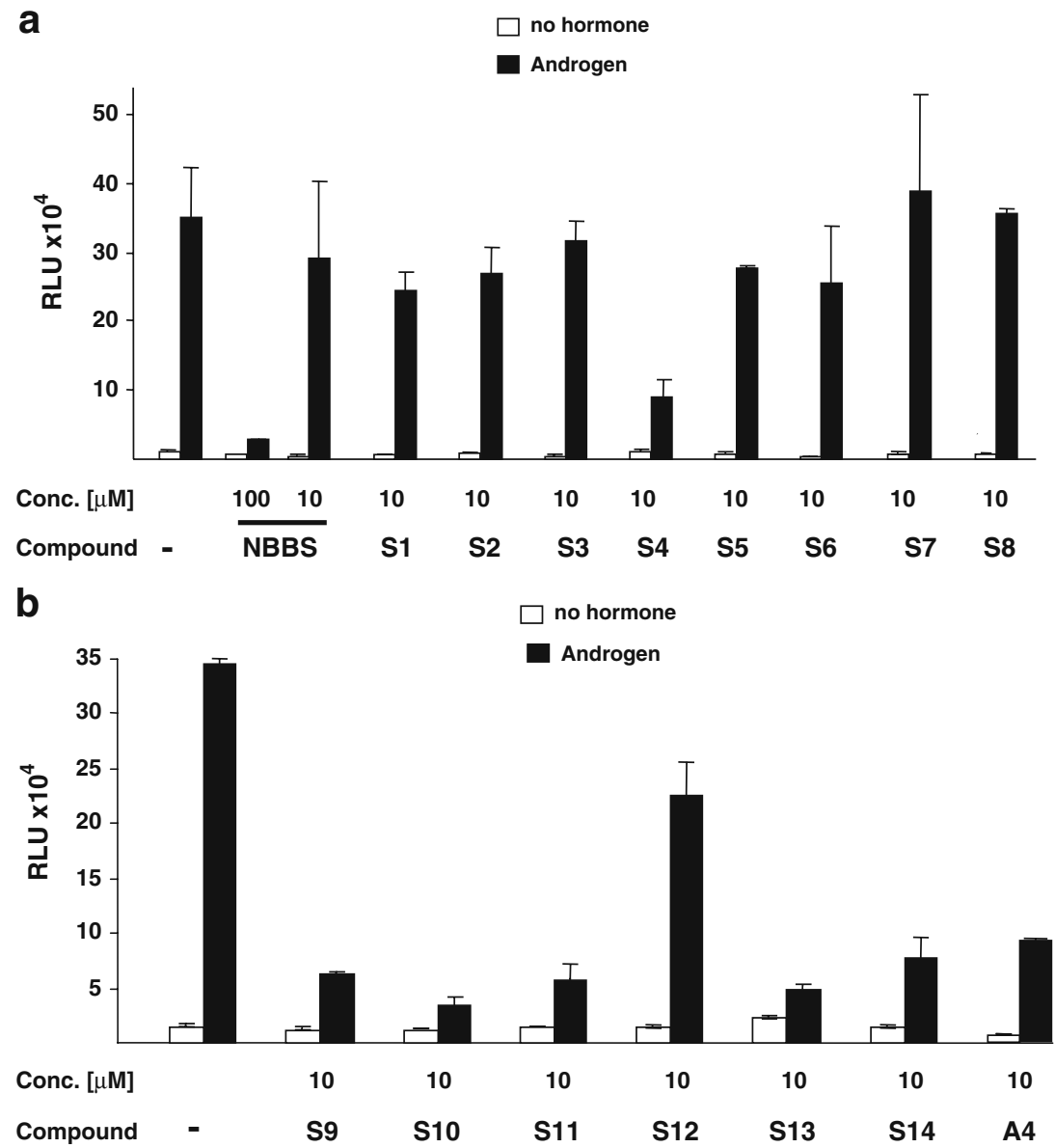

C

GFP-hAR

$\square$ Cytosol

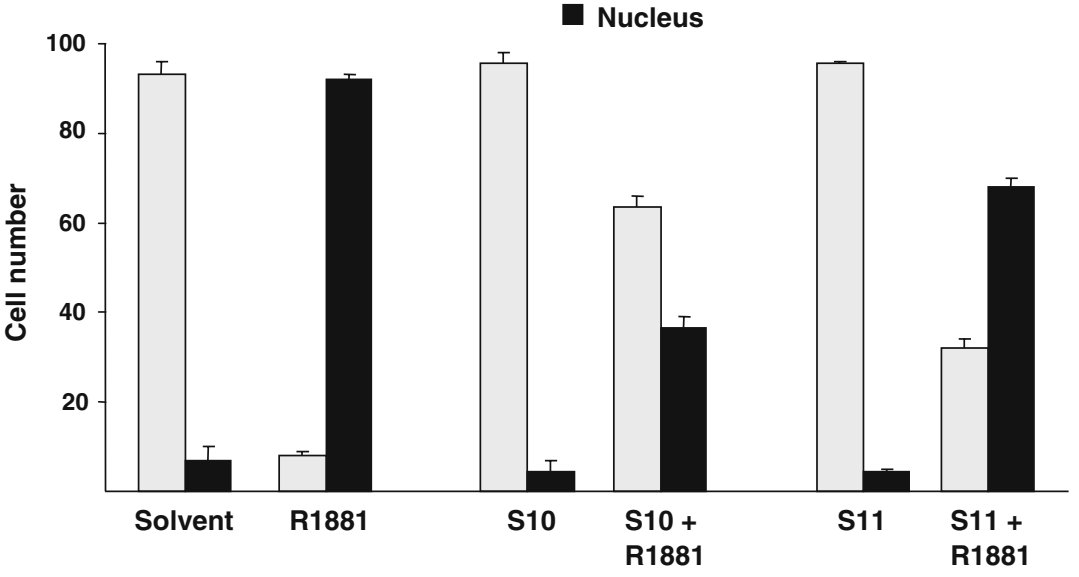

refractory PCa. Also, NBBS derivatives exhibited a similar underlying mechanism to inhibit the androgen-induced translocation of AR at a step prior the action of AR in the nucleus.

Thus, NBBS may serve as a molecule to analyze novel mechanisms to inhibit the AR transactivation and prostate cell growth.
Acknowledgements We greatly thank Dr. O. Jänne, University of Helsinki, Finland, for providing the GFP-hAR expression plasmid.

\section{References}

1. Jemal A, Siegel R, Ward E, Murray T, Xu J, Thun MJ (2007) Cancer statistics. CA Cancer J Clin 57(1):43-66 
2. Shah US, Getzenberg RH (2004) Fingerprinting the diseased prostate: associations between $\mathrm{BPH}$ and prostate cancer. J Cell Biochem 91:161-169

3. Levin RM, Das AK (2000) A scientific basis for the therapeutic effects of Pygeum africanum and Serenoa repens. Urol Res 28:201-209

4. Dehm SM, Tindall DJ (2006) Molecular regulation of androgen action in prostate cancer. J Cell Biochem 99:333-44

5. Dehm SM, Tindall DJ (2007) Androgen receptor structural and functional elements: role and regulation in prostate cancer. Mol Endocrinol 21(12):2855-63

6. Chen S, Xu Y, Yuan X, Bubley GJ, Balk SP (2006) Androgen receptor phosphorylation and stabilization in prostate cancer by cyclin-dependent kinase 1. Proc Natl Acad Sci U S A 103:1596974

7. Tindall DJ (2007) Pursuing the androgen pathway on the quest to control prostate cancer. Cancer Biol Ther 6

8. Taplin ME (2007) Drug insight: role of the androgen receptor in the development and progression of prostate cancer. Nat Clin Pract Oncol 4(4):236-44

9. Balk SP, Knudsen KE (2008) AR, the cell cycle, and prostate cancer. Nucl Recept Signal 6:e001

10. Dehm SM, Regan KM, Schmidt LJ, Tindall DJ (2007) Selective role of an NH2-terminal WxxLF motif for aberrant androgen receptor activation in androgen depletion independent prostate cancer cells. Cancer Res 67(20):10067-77

11. Taplin ME, Bubley GJ, Ko YJ, Small EJ, Upton M, Rajeshkumar B, Balk SP (1999) Selection for androgen receptor mutations in prostate cancers treated with androgen antagonist. Cancer Res 59:2511-5

12. Zhao XY, Malloy PJ, Krishnan AV, Swami S, Navone NM, Peehl DM, Feldman D (2000) Glucocorticoids can promote androgenindependent growth of prostate cancer cells through a mutated androgen receptor. Nat Med 6:703-6

13. Veldscholte J, Berrevoets CA, Brinkmann AO, Grootegoed JA, Mulder E (1992) Anti-androgens and the mutated androgen receptor of LNCaP cells: differential effects on binding affinity, heat-shock protein interaction, and transcription activation. Biochemistry 31(8):2393-9

14. Berrevoets CA, Veldscholte J, Mulder E (1993) Effects of antiandrogens on transformation and transcription activation of wild-type and mutated (LNCaP) androgen receptors. J Steroid Biochem Mol Biol 46(6):731-6

15. Culig Z, Hoffmann J, Erdel M, Eder IE, Hobisch A, Hittmair A, Bartsch G, Utermann G, Schneider MR, Parczyk K, Klocker H (1999) Switch from antagonist to agonist of the androgen receptor bicalutamide is associated with prostate tumour progression in a new model system. Br J Cancer 81:242-51

16. Buck AC (2004) Is there a scientific basis for the therapeutic effects of serenoa repens in benign prostatic hyperplasia? Mechanisms of action. J Urol 172:1792-9

17. Wilt T, Ishani A, Mac Donald R, Rutks I, Stark G (2002) Pygeum africanum for benign prostatic hyperplasia. Cochrane Database Syst Rev (1):CD001044

18. Bombardelli E, Morazzoni P (1997) Prunus Africana (Hook. f.). Kalkm Fitoterapia 68:205-218

19. Yoshimura Y, Yamaguchi O, Bellamy F, Constantinou CE (2003) Effect of Pygeum africanum tadenan on micturition and prostate growth of the rat secondary to coadministered treatment and posttreatment with dihydrotestosterone. Urology 61:474-8

20. Schleich S, Papaioannou M, Baniahmad A, Matusch R (2006) Extracts from Pygeum africanum and other ethnobotanical species with antiandrogenic activity. Planta Med 72(9):807-13

21. Gast A, Schneikert J, Cato AC (1998) N-terminal sequences of the human androgen receptor in DNA binding and transrepressing functions. J Steroid Biochem Mol Biol 65:117-123
22. Dotzlaw H, Moehren U, Mink S, Cato AC, Iniguez Lluhi JA, Baniahmad A (2002) The amino terminus of the human AR is target for corepressor action and antihormone agonism. Mol Endocrinol 16:661-673

23. Leers J, Steiner C, Renkawitz R, Muller M (1994) A thyroid hormone receptor-dependent glucocorticoid induction. Mol Endocrinol 8:440-7

24. Schulz M, Eggert M, Baniahmad A, Dostert A, Heinzel T, Renkawitz R (2002) RU486-induced glucocorticoid receptor agonism is controlled by the receptor $\mathrm{N}$ terminus and by corepressor binding. J Biol Chem 277:26238-43

25. Baniahmad A, Tsai SY, O’Malley BW, Tsai MJ (1992) Kindred S thyroid hormone receptor is an active and constitutive silencer and a repressor for thyroid hormone and retinoic acid responses. Proc Natl Acad Sci U S A 89:10633-7

26. Dotzlaw H, Papaioannou M, Moehren U, Claessens F, Baniahmad A (2003) Agonist-antagonist induced coactivator and corepressor interplay on the human androgen receptor. Mol Cell Endocrinol 213:79-85

27. Protopopov AI, Li J, Winberg G, Gizatullin RZ, Kashuba VI, Klein G, Zabarovsky ER (2002) Human cell lines engineered for tetracycline-regulated expression of tumor suppressor candidate genes from a frequently affected chromosomal region, $3 \mathrm{p} 21$. J Gene Med 4:397-406

28. Peterziel H, Mink S, Schonert A, Becker M, Klocker H, Cato AC (1999) Rapid signalling by androgen receptor in prostate cancer cells. Oncogene 18(46):6322-9

29. Thalmann GN, Anezinis PE, Chang SM, Zhau HE, Kim EE, Hopwood VL, Pathak S, von Eschenbach AC, Chung LW (1994) Androgen-independent cancer progression and bone metastasis in the LNCaP model of human prostate cancer. Cancer Res 54:25772581

30. Tanner TM, Verrijdt G, Rombauts W, Louw A, Hapgood JP, Claessens F (2003) Anti-androgenic properties of Compound A, an analog of a non-steroidal plant compound. Mol Cell Endocrinol 201(1-2):155-64

31. Papaioannou M, Schleich S, Prade I, Degen S, Roell D, Schubert U, Tanner T, Claessens F, Matusch R, Baniahmad A (2008) The natural compound atraric acid is an antagonist of the human androgen receptor inhibiting cellular invasiveness and prostate cancer cell growth. J Cell Mol Med ahead of publication, in press

32. Negri-Cesi P, Motta M (1994) Androgen metabolism in the human prostatic cancer cell line LNCaP. J Steroid Biochem Mol Biol 51:89-96

33. Fedoruk MN, Gimenez-Bonafe P, Guns ES, Mayer LD, Nelson CC (2004) P-glycoprotein increases the efflux of the androgen dihydrotestosterone and reduces androgen responsive gene activity in prostate tumor cells. Prostate 59:77-90

34. Alen P, Claessens F, Verhoeven G, Rombauts W, Peeters B (1999) The androgen receptor amino-terminal domain plays a key role in p160 coactivator-stimulated gene transcription. Mol Cell Biol 19 (9):6085-97

35. Bevan CL, Hoare S, Claessens F, Heery DM, Parker MG (1999) The AF1 and AF2 domains of the androgen receptor interact with distinct regions of SRC1. Mol Cell Biol 19(12):8383-92

36. Liao G, Chen LY, Zhang A, Godavarthy A, Xia F, Ghosh JC, Li H, Chen JD (2003) Regulation of androgen receptor activity by the nuclear receptor corepressor SMRT. J Biol Chem 278 (7):5052-61

37. Shang Y, Myers M, Brown M (2002) Formation of the androgen receptor transcription complex. Mol Cell 9:601-10

38. Kang Z, Jänne OA, Palvimo JJ (2004) Coregulator recruitment and histone modifications in transcriptional regulation by the androgen receptor. Mol Endocrinol 18(11):2633-48

39. Hodgson MC, Astapova I, Cheng S, Lee LJ, Verhoeven MC, Choi E, Balk SP, Hollenberg AN (2005) The androgen receptor recruits 
nuclear receptor CoRepressor $(\mathrm{N}-\mathrm{CoR})$ in the presence of mifepristone via its $\mathrm{N}$ and $\mathrm{C}$ termini revealing a novel molecular mechanism for androgen receptor antagonists. J Biol Chem 280(8):6511-9

40. Moehren U, Papaioannou M, Reeb CA, Hong W, Baniahmad A (2007) Alien interacts with the human androgen receptor and inhibits prostate cancer cell growth. Mol Endocrinol 21:1039-48

41. Kiviharju TM, Lecane PS, Sellers RG, Peehl DM (2002) Antiproliferative and proapoptotic activities of triptolide (PG490), a natural product entering clinical trials, on primary cultures of human prostatic epithelial cells. Clin Cancer Res 8:2666-74

42. Rosenberg Zand RS, Jenkins DJ, Brown TJ, Diamandis EP (2002) Flavonoids can block PSA production by breast and prostate cancer cell lines. Clin Chim Acta 317:17-26

43. Xing N, Chen Y, Mitchell SH, Young CY (2001) Quercetin inhibits the expression and function of the androgen receptor in LNCaP prostate cancer cells. Carcinogenesis 22:409-14

44. Zi X, Agarwal R (1999) Silibinin decreases prostate-specific antigen with cell growth inhibition via G1 arrest, leading to differentiation of prostate carcinoma cells: implications for prostate cancer intervention. Proc Natl Acad Sci U S A 96:7490-5

45. Zi X, Zhang J, Agarwal R, Pollak M (2000) Silibinin up-regulates insulin-like growth factor-binding protein 3 expression and inhibits proliferation of androgen-independent prostate cancer cells. Cancer Res 60:5617-20

46. Thelen P, Jarry H, Ringert RH, Wuttke W (2004) Silibinin downregulates prostate epithelium-derived Ets transcription factor in LNCaP prostate cancer cells. Planta Med 70:397-400

47. Hong CY, Gong EY, Kim K, Suh JH, Ko HM, Lee HJ, Choi HS, Lee K (2005) Modulation of the expression and transactivation of androgen receptor by the basic helix-loop-helix transcription factor Pod-1 through recruitment of histone deacetylase 1. Mol Endocrinol 19(9):2245-57

48. Metzger E, Wissmann M, Yin N, Muller JM, Schneider R, Peters AH, Gunther T, Buettner R, Schuele R (2005) LSD1 demethylates repressive histone marks to promote androgen-receptor-dependent transcription. Nature 437(7057):436-9 